This is an electronic reprint of the original article. This reprint may differ from the original in pagination and typographic detail.

Author(s): Välimaa, Jussi; Nokkala, Terhi

Title: $\quad$ The dimensions of social dynamics in comparative studies on higher education

Year: $\quad 2014$

Version:

Please cite the original version:

Välimaa, J., \& Nokkala, T. (2014). The dimensions of social dynamics in comparative studies on higher education. Higher Education, 67(4), 423-437. https://doi.org/10.1007/s10734-013-9684-y

All material supplied via JYX is protected by copyright and other intellectual property rights, and duplication or sale of all or part of any of the repository collections is not permitted, except that material may be duplicated by you for your research use or educational purposes in electronic or print form. You must obtain permission for any other use. Electronic or print copies may not be offered, whether for sale or otherwise to anyone who is not an authorised user. 


\title{
The Dimensions of social dynamics in comparative studies on higher education
}

\author{
Jussi Välimaa \& Terhi Nokkala
}

motto: "time-space relations cannot be 'pulled-out' of social analysis without undermining the whole enterprise" (Giddens 1984, 286).

\section{Introduction}

The main aim of our article is to discuss social dynamics of higher education because it is one of the most crucial but neglected perspectives in comparative studies of higher education. We will discusses the importance of time, space and contexts -both geographical and sociocultural ones- to reveal how they influence on different social dynamics in various systems of higher education. By social dynamics we refer to the matter of fact that the ways systems of higher education function and operate vary between different countries because of the differences in their various cultural and geographical contexts and in the relationships between various actors. As a concept it makes a reference to Physics where dynamics is a branch which deals with movements and force. We will focus our discussion on the national higher education system level because it provides a suitable level of abstraction for the purposes of this article published in a limited number of pages. However, we hope that these arguments are also considered at the institutional level comparative studies because higher education institutions (HEIs) and their basic operational units are the levels where social life in academia takes place (see Kogan \& Becher 1992). Our main goal is to advance the study of social life in higher education - no matter whether it takes place at individual, basic unit, institutional or system levels. When saying this we do not want to take part in the old(fashioned) debate on the differences between micro and macro sociology (see Giddens 1984). Instead, we approach higher education systems as part of their contexts from a relational perspective (see Emirbayer 1997) paying attention to dynamics created by changing relationships between different actors in given national contexts. Using a terminology of Bourdieu we could say that we are interested in analyzing agents which are struggling for power in national higher education policy fields (Bourdieu \& Wacquant 1992). However, even though we recognize the importance of Bourdieu as one of the relational thinkers, we do not want to tie our thinking to only one sociological theorist because our aim is to challenge traditional (structural functionalist) approach by arguing that higher education systems develop and function differently in relation to their social, historical and spatial contexts which have been improperly discussed so far.

This article is based on two previous publications on comparative research (Välimaa 2009, 2010) and an ongoing large scale comparative research project (Välimaa forthcoming 2014, Nokkala forthcoming 2014) with the hope of advancing the ideas presented in them. The structure of the article is as follows: first, we will discuss different traditions of comparative 
studies in and on higher education to show the main lines of differences in comparative higher education research. Second, we will discuss the basic underlying assumptions of comparative studies, especially structural functionalism. In the third chapter we will discuss the main factors that influence the different social dynamics of higher education system. Finally, we will conclude the main arguments of the study.

We use the concept of 'actor' unwillingly because of its strong connotations in social sciences related to debates on the nature of social change, structures, agency and functions. However, in the lack of a better concept, we use 'actor' as a term to name groups of human beings who have agency and who either work or study in higher education and/or try to influence its functioning.

\section{Debates on the nature of HE studies}

Theoretically, one of the main dividing lines in Western science has been the nature of the interest of knowledge. In humanistic tradition the aim has been to understand (often: human behavior) whereas the aim in the rational tradition has been to explain (often: natural) phenomena (see e.g. Toulmin 1992). This division has been very steep in the Western science and it has led to fundamental differences between natural sciences (typically physics and chemistry) and disciplines studying human behavior (such as education, history, social sciences and psychology). It has been supported by different methodological perspectives both between disciplines and, especially in social sciences, inside disciplines. In the humanist tradition the methods have often been qualitative aiming for interpretations, whereas in the rational tradition they have been quantitative and mathematically-based aiming for creating general principles and universal laws. In the fields of social sciences, humanities and education, rational tradition has normally been named as positivism and its supporters have sworn in the name of one of its developers, Karl Popper, whereas the humanist tradition has been often called as qualitative tradition with a variety of methodological approaches in it (see also Creswell 1998, Delanty 2005).

In the field of higher education research, perhaps the most heated theoretical and methodological discussion between these different traditions took place in the late 1990s when the nature of comparative research was debated by the leading European higher education scholars of the time (see Välimaa 2008 and Higher Education vol 32, 1996). Essentially, the debate was about the goal of comparative studies in higher education. On the one hand, it was argued that causal explanations are the highest goal for comparative (as well as for other social) research. According to this perspective, the best way to reach this goal is to formulate theoretically-based hypotheses, which can be tested with the help of empirical data (Goedegebuure and van Vught 1996). On the other hand, it was argued that there is more than one way of advancing theoretical knowledge on higher education. It was recommended that instead of testing hypotheses we should have thematic comparisons where one uses historically rooted comparative case studies of two or more countries and pays attention to 
their similarities or differences (Kogan 1996). This would allow historically rooted analysis of higher education changes and also produce new theoretical thinking on higher education.

In this article we will not take sides in this old debate but try to find a way to combine both the goals of explaining and understanding the social life in higher education. We also recognize that comparative higher education is especially fertile ground for theoretical debates, because in comparative studies a researcher very soon faces the need to try to explain, or even to give causal explanations, to social phenomena examined because comparative research setting normally reveals both common characteristics and differences between the cases studied, or between the units of analysis (whether individual, departmental, institutional of system). This need for explanations is soon followed by the notion that one cannot make general and generalizing remarks unless one understands deeply the social phenomenon examined in its contexts. The tension between generalizing arguments and contextual understanding of the cases makes comparative studies very different from single country or HEI case studies, because in comparative research setting there is a real and concrete need to find common categories and concepts to study the cases and to explain differences and similarities between them. In typical single case (or country) studies researchers do not see this need very easily because the social dynamics inside a given higher education system follows more or less the same social dynamics and which also feels natural and normal for the researchers living inside the same culture. This 'single country myopia' is, in fact, one of the reasons for problems in comparative higher education studies, because it is all too easy to assume that all higher education systems or institutions follow the social dynamics of one country, HEI or other social entity. This single country myopia seems to especially common with researchers living in a big, or dominant, culture because it is difficult enough to try analyze the complexities and burning issues of the dominant culture itself. However, comparative studies can be real eye-openers both theoretically and practically; for this reason they should be recommended to all higher education researchers.

Comparative research setting is also very political field of research because policy-makers and even fellow academics easily try to find "the best" or "the worst" cases among the analyzed ones - no matter what has been the original purpose of the study. The 'game of competitive interpretations' tends to happen despite the fact that most academics know that the criteria chosen for analysis defines the outcomes reached. In political arenas, in turn, politicians are eager to use comparative studies to advance their own agendas - again, indifferent of the original purposes of the research. For these reasons one of the dimensions often mentioned in comparative education studies is the political context of the object of research (see e.g. Carnoy 2006). Even though there is no clear-cut solution to this state of matters, researchers should be sensitive to the political dimension when conducting comparative studies on and in higher education.

Comparative studies is a political field of research also in the sense that often nation state is taken as a natural unit of analysis -and thus of explaining the differences. This tends to happen easily despite the critique of the dangers of 'methodological nationalism' having revealed the problems and biases it produces (see Dale 2005). In addition to methodological nationalism, higher education researchers easily are biased by institutional parochialism. 
According to Roger Dale institutional parochialism refers to "the tendency within all education studies, including comparative education, (a) to make existing education systems, institutions and practices in isolation the dominant focus of their analyses, and (b) not to problematise these systems, institutions and practices, but to assume that lexical equivalence is sufficient guarantee that the objects being studied are sufficiently similar to make them comparable without further investigation.” (Dale 2005, 134.)

Lexical equivalence is useful term because it pays attention to one of the matters suggested in our article. Namely, we would like to emphasize that instead of lexical equivalences we would like put forward the idea of effective equivalents, which Teichler (in this issue) calls functional equivalents and defines them as different mechanisms serving the same purpose or in reverse, as identical mechanisms serving different purposes in different societies, when making comparisons in higher education. Instead of aiming to find the actors with the same name in different systems of higher education we should try to find higher education actors which serve the same purpose in different systems of higher education, or in the higher education institution compared. In other words, higher education researchers should take seriously the matter of fact that the functions of different actors in their respective contexts may vary because of different social dynamics. Social dynamics, in turn, should be understood as a concept which consist of a conceptual duality where different time-space conditions not only create contexts for human behavior, but which also are shaped by human beings and their actions.

\section{Basic assumptions on the social dynamics of higher education systems}

Before explaining what causes and influences differences in the social dynamics of systems of higher education we need to reflect on the traditional way of reasoning in comparative higher education research. This reflection also helps us to understand why the theme of social dynamics has been neglected in comparative higher education research so far.

We would like to suggest that the fundamental basic underlying assumptions in the field of comparative higher education research has been the following one: all higher education systems follow the same logic of functioning, because they have the same actors and structures of the higher education system (students, academic staff, higher education institutions both private \& public, ministry of education) which follow the same objectives and motivations (to get a degree/students, become famous/academics, become world class universities/HEIs or use national or public resources efficiently/ministry of education). It is this reduced approach to comparative higher education research we criticise as structural functionalism because of its underlying basic assumption that all higher education systems serve the same purposes (see criticism of functionalism in Giddens 1984). ${ }^{\mathrm{i}}$

This structural functionalistic logic of reasoning normally begins with theoretical assumptions on the importance of the division of labour between different levels of the system of higher education, on the need to have functional structures and on the assumption that actors have different roles in the structures. It then continues with the originally 
Durkheimian reasoning which pays attention to the social forces of integration and disintegration of the system. The classical work by Burton Clark (1983) with its famous triangle of coordination pays accordingly attention mainly to structural characteristics of national higher education systems. Despite obvious problems in the operationalization of this useful heuristic device (see Huisman 1995, Välimaa 1997), it has been used in comparative studies in the lack of a better model. This instrument pays attention to social forces which bring integration to the national systems of higher education through the main principles of integrative actions represented by the state, market and academia. This is not to criticize the Clark's triangle as such. It is a decent heuristic which reduces complexity of the higher education systems thus making it more feasible to study them. This way of reasoning does not, however, leave room for thinking that all higher education systems do not necessarily follow the same functionalistic social dynamics because of its underlying rational assumption that the same lexical equivalence produces the same social dynamics.

An additional, pragmatic reason for the popularity of a functionalistic perspective may be rooted in the fact that in the comparative analyses of higher education especially in the European context (see Enders 2001, Westerheijden \& Schwartz 2004), it has been practical to focus analytical attention to the national system of higher education instead of trying to see higher education systems as part of their social and historical contexts or geographical spaces. Unit of analysis, then, supports a functionalistic approach, in other words: paying attention to higher education as a social system in its own right. As already Kelly and Altbach $(1986,95)$ argued structural functionalism "places too much stress on the national setting and not on the roles that education might play in society and its myriad institutions".

For example, in a hypothetical research of community college students in an international comparative setting, we would see quite easily that the basic problem with this study would be the fact that (American) community colleges do not really exist outside the United States. The challenge then is to find effective equivalents, HEIs which serve the same social purposes in different higher education systems. Therefore, instead of asking what kinds of community colleges (or other country-specific educational institutions) exist in other countries, one should ask: what are the educational opportunities for students leaving compulsory education? Or what are the educational opportunities for adults who would like to continue their studies? Answering these questions would help to see the social dynamics of different countries in comparison to the students who go to community colleges in the US higher education. Effective equivalents reflect the different social dynamics which have caused higher education systems to evolve in different directions. In order to be able to identify effective equivalents of a particular organisational form or societal process, one must be able to understand the underlying factors causing these social dynamics. To continue the example of community colleges presented above, their effective equivalents in other countries are shaped by the structure and size of the secondary and higher education systems, and of the labour markets. Thus in Finland, for example, the polytechnic institutions, open universities and folkhögskola would all comprise effective equivalents to community colleges.

How to take into account the fact that higher education systems follow different social dynamics? This basic question can be revealed from four different perspectives. First, it is 
more than evident that all actors in systems of higher education do not share the same motivations. Academics, students and ministries of education have different goals, objectives and resources even though in principle they globally have the same objectives. For example, in a developing country even making a living as an academic may be a hard experience for academics (cf. Latin American countries). As for students, a higher education degree does not guarantee a good position in a credential society where there are plenty of higher education graduates. In a pre-mass higher education system the situation is normally contrary to credential society.

Secondly -and this is crucially important for the social dynamics of higher education- the political influence of different actors may, and do, vary between countries. For example, in some countries student organizations are powerful actors in national politics (like in Mexico and Finland) whereas in other countries they are organized according to HEIs (like in Portugal) or do not have a strong voice in the national political scenes (see Ordorika 2003, Välimaa 2012). In some countries HEIs have a buffer organization (like VSNU in the Netherlands, http://www.vsnu.nl) which are influential actors helping to create integration among HEIs, whereas in other countries the actor with the same name (rectors conference) may only be a symbolic and weak actor (like in Finland).

Thirdly, the relationships between different actors vary between countries. Even though we can find the ministries of education from practically every country, their roles in national higher education policy-making may vary. For example, in Ireland a crucial actor in the making and implementing of the Irish higher education policy is Higher Education Authority, which takes care of the practicalities of policy-making and the evaluation and assessment of Irish HEIs under the Irish ministry of education (see http://www.hea.ie/). In principle, it is not a political but a neutral expert actor, whereas in many continental European countries ministries of education do not need this kind of neutral actor to implement their policies. We may also consider the impact of the particular organizational context on the policy-making and policy rationales in a given policy area. The ministry focused on business and innovation conceivably constitutes a different policy environment from a ministry focused on, say, education, youth and culture. A good example of this is the United Kingdom, where in the past two decades, higher education has been a responsibility of five different organizational constellations: the Department of Education, created in 1992, the Department for Education and Employment in 1995, the Department of Education and Skills in 2001, the Department of Innovation, Universities and Skills in 2007 and finally the Department for Business, Innovation and Skills in 2009. The structure of the country should also be taken into account, because single nation state differs significantly from a federal state not only because of its size but also because the federal structure introduces another layer to the steering and funding of higher education. (Nokkala forthcoming 2014) The roles of the ministries of finance also vary between countries. Even though it seems that New Public Management has strengthened the power of the purse -and that of the ministry of finances- the situations do vary between countries.

Finally, in addition to these political actors, also academic labor unions can be found which aim to have influence on national and local level political processes related especially to 
working conditions of academics. Again, the importance and political contacts of the academic labor unions vary between countries. In Nordic countries academic labor unions are normally nation-wide organizations which do not represent any political party, or ideology, because their aim is to protect their membership which may belong to different political parties. In the Southern European countries we see a contrary case: academic labor unions normally represent only one political fraction or party (see Enders 2001). In addition to these matters, industry and business organizations, or big firms, may be politically active. This is especially the case with innovation and technology policies at the national level. At the institutional level, in turn, cooperation between firms and entrepreneurs may have influence on social life in academia (Slaughter and Rhoades 2004, Välimaa 1998).

The economistic way of reasoning has introduced the concept of stakeholder to higher education. This concept aims to say that in addition to traditional actors in the field of higher education we also should pay attention to business enterprises, students and their parents as customers. Again, this ideology has different importance in different countries.

With these examples we would like put forward the argument that there are real needs to study in details how powerful are the different actors and what are their mutual relationships in each of the cases studied. We also would like to pay attention to the fact that despite finding the same names of the actors (lexical equivalence) in different higher education systems, we cannot assume that their mutual relationships or their motivations or political influence are the same everywhere. For this reason we cannot assume that the social dynamics of different higher systems follow the same logic. Instead, we should see that analyzing differences is one of the main goals of comparative higher education research no matter whether we are interested in formulating generalizations, which at their best are historical generalizations tied to time and space, or ethnographic studies focusing on HEIs in local contexts (see also Giddens 1984).

\section{What influences different social dynamics in higher education systems}

We have stated above many times that higher education systems and their social dynamics vary between different countries. We have also criticized quite heavily the traditional approaches of comparative studies in higher education. It is time to build a more positive argumentation to discuss what we mean by social dynamics and what causes the differences. This helps to open new perspectives to comparative studies in the future.

With the help of social dynamics we try to answer to the following big questions: how does the system of higher education or HEI work in reality? What happens in the social life of academia? To be able to answer these big questions in comparative higher education research we need to reflect upon three big themes in social sciences, history and geography. These are time, space and context. These categories were introduced by Anthony Giddens in his ambitious attempt of a Grand Social Theory (Giddens 1984). We argue that they are useful as intellectual devices, even though we do not necessary share all the ideas of Giddens's theory. 
The idea of taking the environment of a social system seriously is not brand new. In fact, it is as old as historical thinking which has always paid attention to the context, time and space where human beings live. Taking context seriously is one of the starting points for any historical study, but it is especially strong in the tradition of Annales School in France with Ferdnand Braudel being its most famous proponent with his analysis of the interplay between human beings and their environment in a historical continuum in the Mediterranean region (Braudel 1949). In addition to history, the discipline of geography and especially human geography has taken the interaction between a geographical region and its population very seriously (see e.g. Johnston 1986). To put it very briefly, in human geography space (and its operationalization as region or some other concrete geographical location or place) emerges in relation to society and to culture. It is interpreted individually by human beings and it ties itself into the lives of human beings through societal processes. In other words, geographical space is not just geographical space but it is also a cultural experience and a societal matter of fact. Geography, society and culture are therefore interwoven with each other in many ways through different kinds of social and material interactions. (Häkli 1999, 80-84)

Originally, already Montesquieu, a political philosopher of the Enlightenment, paid attention to the interplay between geography and human beings in his treatise The Spirit of the Laws (1748) where he explained with the help of $18^{\text {th }}$ century concepts that climate, soil and geography affect the temperaments and customs of a country's inhabitants. For Montesquieu the challenge was to take these human characteristics into account in a country's legislation (see Althusser 2007). The idea on the influence of geography can also be found in the thinking of Marx in his often quoted phrase "Men [let us immediately say human beings] make history, but not in the circumstances of their own choosing" (in Giddens 1984, xxi). This argument is developed further by Anthony Giddens in his theory of structuration. A crucial theme in this social theory is the reflection of the relationship between actors and structures and the environment where these reside. Giddens argues that "the situated nature of social interaction can usefully be examined in relation to the different locales through which the daily activities of individuals are co-ordinated. Locales are not places but settings of interaction". Giddens continues his reasoning by stating that "Time-space 'fixity' also normally means social fixity; the substantially 'given' character of the physical milieux of day-to-day life interlaces with routine and is deeply influential in the contours of institutional reproduction." (Giddens 1984, xxv). We would like to continue this line of argumentation and emphasize that time, space and historical context influence human behavior because they shape the cultural and economic conditions in which and under which different social system emerge and develop. This is also one of the reasons why we do not have a 'Humboldtian university' outside Germany because the idea of a Humboldtian university has been interpreted differently in different time-space contexts in a way which produces an interpretation of the German idea instead of imitation of a German model (see e.g. Perkin 1984). We take Humboldtian university as one example even though the same may be repeated with the idea of (the American) Research University, or a World Class University, or many higher education reforms which have spread over the globe like diseases. The virus is the same but the diseases are different as Teichler (2004) puts it, because social contexts are different. Again, trying to define effective equivalents serves better the needs to find 
similarities than the assumption that the actors with the same names follow the same rationale.

\section{So, nihil novi sub sole?}

Even this short introduction helps to see that time and space have been recognized in Western humanist tradition. It also reminds us about the potential misuses of these concepts if they are used mechanically as causal explanation machines. However, the richness of this tradition challenges us to ask: why has higher education research as a field neglected the perspective of social dynamics, especially in comparative studies? Why we have not taken into account the facts that have been part of the body of knowledge in geography, history and even sociology?

Part of the answer to this question is probably rooted in the strong traditional (structural functionalist) perspective of higher education comparative studies which -in its eagerness to name the actors- has overlooked the need to see the contexts of the actions and the actors. In what follows we will not pay attention to actors when discussing more deeply the nature of time, space and context. The idenfication of actors should be a task for empirical studies. These categories are meant for heuristic devices, the use of which should be considered separately in each case. The idea is to use the following categories as a checking list to be considered before and during making comparative studies on and in higher education.

\section{Geographical space}

Geographical space refers here to the geographical formations and natural conditions at the locales of the object of study. This is important because historically speaking geographical formations have influenced the means of transportation and communication of human beings. Before electronic means of communication these two categories were inseparable because communication meant the movement of human bodies in space as well For this reason geographical space has not only helped to create patterns of interaction and orientations of communication but also influenced on the conditions for economic development. Space also influences the communication patterns, modes of transportation and density of population. As for higher education, geographical spaces and modes of transportation are crucial matters to be taken into account to understand the locations of higher education institutions. Consider a HE system on an island (like Japan, or UK), or in a mountainous region (like Switzerland), or on a continent (like Poland, or Germany). Each of them has different economic and cultural orientations and different kinds of contacts with their neighboring countries/cultures due to their geographical space. For example, how have the isolated environments of US Land Grant Universities influenced their college cultures? We could also reflect upon the relationship between the locality of campus and the student population it serves: how does the location of the campus influence the study population? Consider greenfield campuses vs. urban colleges.

Historically speaking, these are preconditions for the development of higher education systems and institutions as well. Region in which the higher education institutions are located is also crucially important, because it influences on the missions of higher education institutions and on the everyday practices of academic social life. Consider also different 
tasks or missions, and ways of organizing higher education institutions in the national centre or periphery, or in economically thriving regions vis-á-vis regions facing structural economic downturn.

\section{Climate}

Climate is one of the natural conditions for the social life of human beings which has been totally neglected theoretically even though it is recognized in everyday life of academics when we discuss weather -one of the visible outcomes of climatic conditions- in international conferences with our colleagues. We would like to pay attention to the fact that the working conditions in hot weather conditions differ significantly from those in cold weather conditions. The efficient working time is rather limited if societies are not prepared for hot weather conditions (air conditioning) or cold weather conditions (heating houses). The significance of climate can also be seen in the fact that modern societies try to manipulate the climatic conditions inside buildings through air conditioning or heating houses. The economic resources of societies are, naturally, related to how successfully societies manage to manipulate weather conditions. In cold weather conditions, like in the Nordic countries, climate clearly has influence on the yearly rhythm of working as well. Summer holidays always take place during the 'best' summer months (June and July) when societies (including HEIs) are practically 'closed'. The difference in the yearly rhythm of societies causes many practical problems inside the European Union, where the official vacations take place on August thus following a Central and Southern European understandings of a proper summer. Climatic conditions are also related to the time structure of academic year with significant variations with the number of terms and their timing.

We may learn a lot from human geography, which is more advanced in making use of the categories of geographical space and climate in understanding the contexts affecting the social systems and human behavior (Häkli 1999). They not only provide geo-political conditions for societies, economics and cultures to develop, but also influence the ways of communication and interaction between human beings and their ways of organizing their everyday social life and institutions, even though one should remember that these complex relationships should not be understood or explained mechanically. In principle, geographical space and climate are important because they influence the living conditions of human beings. For this reason they should be understood as cultural categories. With cultural categories we mean to say that we should take seriously their influence on human behavior, daily routines of students, academics and managers, and interactions between different actors. This way they also influence the social dynamics of higher education.

\section{Time and context}

Time, space and context have been discussed in elaborated theoretical ways by Giddens (1984) among others. Time and context are also the most common intellectual devices used by historians. However, when speaking about time we should consider that there are different 
understandings on the nature of time -and here we are not speaking about everyday experiences of academics following different clock time or different definitions of keeping the schedules in research projects. Our aim is to pay attention to the fact that in some cultures time is linear whereas in others it is cyclical. Time has also a more abstract meaning which is especially emphasized by Giddens (1984), who pays attention to the fact that human bodies are normally tied by time because one human being can only be in one physical place at one time. Time and place are tied together, because when a human being moves in time he also moves in a geographical place. However, these traditional categories are being challenged by globalized world where ICT helps to create social spaces which are separated from physical space, because human beings can create their own social spaces -like social media- which are indifferent of geographical space (Castells et al.2006). Historically speaking, however, time and space have been bounding categories for the development of human cultures and civilizations, higher education institutions being one the social institutions created.

In academic history writing, a crucial challenge is to understand and explain how historical events that have taken place simultaneously are connected with -or disconnected from- each other. In other words, what are the circumstances that have influenced the historical process under study. This brings us to the concept of historical context. Understanding historical context normally helps to explain the ways of thinking of the people in the past, and the material conditions of their life. Historians often pay attention to continuities and discontinuities in their studies of the past regardless of whether they study ideas or belief systems (like religions, science and scholarship), economies, or political events and cultural changes. Higher education institutions, especially universities, have been in the core of the cultural processes of civilizations and have also influenced the economic development of their geographical spaces - especially in the modern times. The study of the university revolutions is helpful in this regard because it shows how universities have interacted with their societies many different ways (se Nybom 2007). This kind of historical perspective also helps to understand that the development of higher education is not a smooth linear success story but more like a narrative full of tensions between universities and their societies. Historical studies also help to see that there are many traditions, legacies and historical layers in higher education institutions all of which have been shaped by the interactions taking place in time and context.

For these reasons, understanding the limitations of time and geographical space, and the connections between social, cultural and economic contexts are crucially important to explain the development of social dynamics of higher education in a given geographical space.

\section{More practical perspectives for comparative higher education research}

In addition to rather high-flying abstract perspectives suggested above as a check list for comparative studies, we should also discuss how these factors interplay in the systems of higher education. When saying this we would like to emphasize the fact that the development of a national system of higher education is always a historical process where time, space and contexts shape different actors in their interactions with each other. Historically speaking we 
can describe this phenomenon with the help of historical layers, which -like archaeological layers- are structured by preceding historical developments and daily routines, where previous layers may continuously influence the intellectual landscapes and everyday practices, and administrative routines in higher education institutions thus creating new historical layers (see Välimaa 2007).

\section{Size and higher education system characteristics}

The size of the national higher education system has an impact on the social dynamics of national higher education systems (small systems vs. large systems). The social dynamics of small European nation states, where it is possible to learn to know all important persons in the field concerned, differ from the large systems of higher education, whether small systems have reached the point of a 'mass higher education' or not. The size also impacts on the need for additional administrative layers between national and local level. These may be geographically organized, as is the case in federal states. A federal state (with both federal and state level ministries of education) or a single nation state creates very different sociopolitical dynamics for higher education. Federal states have more complicated legislative structures and distribution of power compared to single nation states. Alternatively, the additional layers may also be functionally organized, for example, through a separate funding council for higher education. Additional layers, be they geographical or functional, add complexity through adding a level of political struggle.

International trends also impinge differently, and on different time scales on the operational logics of large and small higher education systems. Small systems may be more flexible to change their operations (think of the early implementation of the Bologna Process), yet large systems may be the ones creating trends which other systems must emulate (think of commercialisation of higher education).

\section{Language}

The social dynamics in small language areas differ significantly from those of the large language areas, because of the simple fact that there are only a limited number of academic positions -and opportunities for academics- in small language areas. Similarly, small language areas are more likely to accommodate the dominance of English language in their operations, while large language areas are more likely to rely on their own language to maintain a competitive edge in international higher education markets.

\section{Societal actors or stakeholders}

The collective bargaining power of the academic trade unions and the political power of the student organizations may play a role in matters dealing with student life, academic work and profession. In Northern Europe one tends to find unified and strong academic trade unions with weak political agendas, whereas in Southern European countries the contrary is often the case. As for student organizations, Japan provides an example of insignificant student unions, 
because of their rebellious history in the 1960s, whereas in Latin American universities the contrary is the case.

Business enterprises or regional or national organizations representing industrial or business interests have different power positions in different societies. Economic and business stakeholders and pressure groups may have influence on the social life in system and institutional levels (see Slaughter and Rhodes 2004).

\section{The societal traditions of universities and higher education}

Societal traditions of higher education institutions may play a significant role in the social dynamics of national systems of higher education. This is especially true in systems of higher education, where universities have had strong cultural and political nation building function like in Finland, Norway or Australia (see Välimaa 2012, Bleiklie et al. 2000, Marginson 2002) or state building function, as in Mexico (Ordorika and Pusser 2007). In these systems, the development of the higher education system is inseparable from the development of the national identity and the sense of nationhood, or respectively, "in the development, expansion and maintenance of the state as an integral entity" (Ordorika and Pusser 2007, 191). The nation and state building functions have guided the establishment of regional universities, the adoption of the national language as the language of science or the elaboration of the mission of the higher education institutions.

Alternatively, the main function of a higher education system may be that of social reproduction. This is specifically evident in the old class systems such as United Kingdom or France. The organizational forms in which this reproduction takes place may vary; for example in United Kingdom, the old prestigious universities such as Oxford and Cambridge still act as stalwarts of social privilege, whilst in France the Grands Écoles fulfill the same function. (Tapper \& Palfreyman 2010, Deer 2005)

\section{Colonial traditions}

Spatial matters are also important in a globalized world, where colonial heritage continues to have an impact on the systems of higher education in previous British, American and French dominions (see Altbach 1998). Upon their independence many African countries with former colonial ties modeled the structure of the higher education system, the organization of the university administration or the degree structure and curriculum closely to the traditions of the former colonial masters. While the tide may be changing the old traditions continue to exert influence over the reorganized higher education systems.(See e.g. Materu, Obanya and Righetti 2011.)

\section{Conclusions}

We have used the concepts of social life and social dynamics together because we would like to pay attention to the fact that everyday practices and routines of academics produce and are 
reproduced by academic structures and social dynamics of the higher education system. Social life in academia and the social dynamics of higher education systems and higher education institutions are interwoven with each other. Typical to higher education is that contemporary higher education institutions are influenced by many and often contradicting expectations from civil society, business, industry, NGOs and taxpayers. HEIs are expected to be high quality research sites with extensive education and training programs and giving a significant regional impact on local economies and communities (see Välimaa 2007).

Many of these expectations and societal tasks have been given to universities -or have been adopted by universities- over the course of their history. Therefore, the study of contemporary higher education should take history as one of its starting points because traditions of higher education institutions have developed and changed over time in geographical and cultural contexts. Social dynamics are influenced by traditions. However, we would like to emphasize that history alone is not a sufficient perspective to understand and explain the development and contemporary activities of higher education institutions. We have also criticized functionalistic tradition as too mechanistic a perspective to higher education because this tradition assumes that higher education plays the same social function in every society, or, respectively, that organizations named the same play the same role within different higher education systems. However, this is not the case. Therefore, we would like to suggest that social dynamics provides a fresh perspective to comparative higher education research because it focuses attention to the fact that higher education systems - and higher education institutions have always been in interaction with their locales and societal contexts. The combinations of these relationships taking place in time, space and context have produced different social dynamics for higher education systems and institutions. For these reasons the comparative study of higher education may benefit from the perspective of social dynamics, because it is less interested in finding similar functions of higher education systems through the examination of lexical equivalences but aims to find effective equivalences. This kind of comparative higher education studies may utilize many different methodological perspectives and intellectual devices. Crucially important is to understand that higher education is -and has always been- a part of their societies. Taking this notion seriously is the most important starting point in analyzing what kinds of social dynamics can be found in higher education to better understand the social life in academia.

\section{References:}

Althusser, L. (2007) Politics and History: Montesquieu, Rousseau, Marx, Ben Brewster (trans.), London: Verso

Bleiklie, I. Roar H. and Vabo, A. (2000). Policy and Practice in Higher Education. Reforming Norwegian Universities.

Bourdieu, P. \& Wacquant, L.J.D (1992) An Invitation to Reflexive Sociology. Chicago: University of Chicago Press. 
Braudel, F. (1949) La Méditerranée et le monde méditerranéen à l'époque de Philippe II. Paris.

Carnoy, M. (2006). 'Rethinking the Comparative -and the International', Comparative Education Review (50), 4, 551-570.

Castells, M., Fernandez-Ardevol, M., Qiu, J.L (2006). Mobile Communication and Society: Global Perspective. Cambridge, MA, USA: MIT Press.

Clark, B.R. (1983). The Higher Education System. Berkeley: University of California. Creswell, J.W. (1998) Qualitative Inquiry and Research Design. Choosing among Five Traditions. Thousand Oaks: Sage.

Dale, R. (2005) Globalisation, knowledge economy and comparative education, Comparative Education, 41(2), 117-149.

Deer, C. (2005). Higher education access and expansion: the French experience. Higher Education Quarterly, 59, 230-241.

Delanty, G. (2005) Social Science. Philosophical and Methodological Foundations. Second Edition. Berkshire: Open University Press.

Emirbayer,M. (1997) 'Manifesto for a Relational Sociology', American Journal of Sociology, Vol 103, No. 2, 281-317.

Enders, J. (ed.) (2001) Academic Staff in Europe: Changing Contexts and Conditions. London: Greenwood Publishing Group

Giddens, A. (1984) The Constitution of Society: Outline of the Theory of Structuration. University of California Press.

Goedebuure, L. and van Vught, F.A. (1996). 'Comparative higher education studies: The perspective from the policy science', Higher Education (32), 371-394.

Huisman, J. (1995) Differentiation, diversity and dependency in higher education. A theoretical and empirical analysis. Lemma.

Häkli, J. (1999) Meta Hodos. Johdatus ihmismaantieteeseen. Tampere: Vastapaino.1999 Johnston, R.J. (1986) Philosophy and Human Geography. An introduction to Contemporary Appraoches. $2^{\text {nd }}$ ed., London: Arnold.

Kelly, G.P. 6 Altbach, P.G. (1986), Comparative Education: Challenge and Response. Comparative Education Review, Vol 30, No. 1 (Feb 1986), pp. 89-107.

Kogan and Becher (1992) Process and Structure in Higher Education. Second edition. London \& New York: Routledge.

Kogan, M. (1996). 'Comparing higher education systems', Higher Education (32), 370-395. 
Marginson, S. (2002). 'Nation-building universities in a global environment: The case of Australia', Higher education, 43(3), 409-428.

Materu, P.; Obanya, P. Righetti, P. (2011). The Rise, Fall, and Reemergence of the University of Ibadjab, Nigeria. In Altbach, P.G and Salmi, J. (Eds.) The Road to Academic Excellence - The Making of World-Class Research Universities. Washington: The World Bank, pp. 195-228.

Nokkala, T. (Forthcoming 2014) National stories, convergent trends and divergent paths knowledge society and higher education discourse. In: Välimaa, J. \& Hoffman, D. (Eds.) (Forthcoming 2014). Change in Networks, Higher Education and Knowledge Societies. Dordrecht: Springer.

Nybom, T. (2007) A Rule-Governed Community of Scholars: The Humboldt Vision in the History of The European University. In P. Maassen \& J.P. Olsen (eds.) University Dynamics and European Integration. Springer: Higher Education Dynamics 19, pp. 55-80.

Ordorika, I. (2003) Power and Politics in University Governance. Organization and Change at the Universidad nacional Autónoma se México. New York \& London: RoutledgeFalmer.

Ordorika, I. and Pusser, B. (2007). La máxima casa de estudios: Universidad Nacional Autónoma de México as a state-building university. In P. G. Altbach and J. Balán (Eds.), World-class worldwide: Transforming research universities in Asia and Latin America. Baltimore: Johns Hopkins University Press, 189-215.

Perkin, H. (1984), The Historical Perspective. Perspectives on Higher Education. Eight Disciplinary and Comparative Views. Berkeley, Los Angeles, London: Univerisity of California Press.

Schwarz, S \& Westerheijden, D.F. (eds.) (2004) Accreditation and Evaluation in the European Higher Education Area. Dordrecht: KluwerSlaughter, S. and Rhoades, G. (2004) Academic Capitalism and the New Economy: Markets, State, and Higher Education. Baltimore: Johns Hopkins University Press.

Tapper, T. and Palfreyman, D. (2010). The Collegial Tradition in the Age of Mass Higher Education. Dordrecht: Springer.

Teichler, U. (1996). 'Comparative higher education: potentials and limits', Higher Education (32), 431-465.

Teichler, U. (2004), 'The changing debate on internationalisation of higher education', Higher Education 48 (1), 5-26.

Teichler, U. (in this issue). Opportunities and Problems of Comparative Higher Education Research: The Daily Life of Research. Higher Education Special issue on Comparative HE Research.

Toulmin, S. (1992) Cosmopolis. The Hidden Agenda of Modernity. Chicago. Chicago University press. 
Välimaa, J. (1997) Integraatio, differentiaatio ja Clarkin kolmio. In J. Välimaa (ed.) Korkeakoulutus kolmiossa -näkökulmia korkeakoululaitoksen muutoksiin. [Higher Education in a Triangle-Perspectives to changes in higher education] Jyväskylä: Koulutuksen tutkimuslaitos, 13-34.

Välimaa, J. (2012) The Corporatization of National Universities in Finland, in B. Pusser, K. Kempner, S. Marginson, and I. Ordorika (Eds.) Universities and the Public Sphere. Knowledge Creation and State Building in the Era of Globalization. New York: Routledge, 101-120.

Välimaa, J. (Forthcoming 2014) Higher Education institutions in Networked Knowledge Societies. In: Välimaa, J. \& Hoffman, D. (Eds.) (Forthcoming 2014). Change in Networks, Higher Education and Knowledge Societies. Dordrecht: Springer.

Välimaa, J. (2010). Kenttätieto vertailevassa korkeakoulututkimuksessa. Kasvatus 4/2010, 363-373.

Välimaa, J. (2004) Nationalisation, localisation and globalisation in Finnish higher education. Higher Education 48: 27-54

Välimaa, J. (2008). On Comparative Research in Higher Education, in A. Amaral, I. Bleiklie and C. Musselin (eds.) From Governance to Identity -A Festschrift for Mary Henkel. Higher Education Dynamics 24. Springer, 141-155.

Välimaa, J. (2009). On Field Knowledge in Higher Education. In Higher Education Forum. Vol. 6, March. RIHE, Hiroshima University, 73-86.

Välimaa, J. (2007) On Traditions and Historical Layers in Higher Education. In Jurgen Enders \& F.A. van Vught (eds.) Towards a cartography of higher education policy change. Festschrift in honour of Guy Neave. Enschede: CHEPS, 67-76

\footnotetext{
'According to Giddens (1984) functionalism strongly emphasises the pre-eminence of the social world over its individual parts (i.e. its constituent actors, human subjects).
} 